\title{
Public hearings as a tool to improve participation in regulatory policies: case study of the National Agency of Electric Energy
}

\author{
Camila Moreira de Castro \\ Zeppelin University (Germany)
}

\begin{abstract}
The participation of citizens in public policies is an opportunity not only to educate them, but also to increase their empowerment. However, the best way for deploying participatory policies, defining their scope and approach, still remains an open and continuous debate. Using as a case study the Brazilian National Agency of Electric Energy (Aneel), with its public hearings about tariff review, this paper aims at analyzing the democratic aspects of these hearings and challenges the hypothesis of many scholars about the social participation bias in this kind of procedure. This study points out a majority participation of experts, contrasting with the political content of discussions. And, this way, it contributes to a critical analysis of the public hearings as a participatory tool, indicating their strengths and their aspects which deserve a special attention.
\end{abstract}

KEYWORDs: public hearings; Aneel; participation; deliberative democracy; public policies.

Audiências públicas como instrumento para melhorar a participação em políticas regulatórias: estudo de caso da Agência Nacional de Energia Elétrica

A participação de cidadãos em políticas públicas é uma oportunidade não apenas para educá-los, mas, também, para aumentar seu empoderamento. No entanto, a melhor forma de implementar políticas participatórias, de definir sua abrangência e abordagem, ainda é um debate aberto e constante. Utilizando como estudo de caso a Agência Nacional de Energia Elétrica (Aneel) brasileira, com suas audiências públicas sobre revisão tarifária, este artigo objetiva analisar os aspectos democráticos dessas audiências e questionar a hipótese de muitos estudiosos sobre o viés da participação social nesse tipo de procedimento. Este estudo aponta uma participação majoritária de especialistas, contrastando com o conteúdo político das discussões. E, nesse sentido, contribui para uma análise crítica das audiências públicas como instrumento de participação, pontuando seus pontos fortes e aqueles que merecem atenção especial.

Palavras-chave: audiências públicas; Aneel; participação; democracia deliberativa; políticas públicas.

Article submitted on 14 Nov. 2012 and accepted for publication on 24 June 2013. 


\begin{abstract}
Audiencias públicas como un instrumento para mejorar la participación en políticas reguladoras: estudio de caso de la Agencia Nacional de Energía Eléctrica

La participación de ciudadanos en políticas públicas es una oportunidad no sólo para educarlos, pero también para aumentar su empoderamiento. Sin embargo, la mejor manera para implementar políticas reguladoras, para definir su alcance y enfoque, es todavía un proceso abierto y constante. Utilizando como estudio de caso la Agencia Nacional de Energía Eléctrica (Aneel) brasileña, con sus audiencias públicas acerca de la revisión tarifaria, este artículo tiene como objetivo examinar los aspectos democráticos de esas audiencias y cuestionar la hipótesis de muchos académicos acerca del sesgo de la participación social en ese tipo de procedimiento. Este estudio apunta una participación mayoritaria de expertos, en contraste con el contenido político de las discusiones. Y, en ese sentido, contribuye a un análisis crítico de las audiencias públicas como instrumento de participación, indicando sus puntos fuertes y aquellos que merecen una atención especial.
\end{abstract}

Palabras clave: audiencias públicas; Aneel; participación; democracia deliberativa; políticas públicas.

\title{
1. Introduction
}

Over the recent years, the role of government has been constantly challenged, with an increasing emphasis on engaging citizens and empowering stakeholders during the planning and deployment of programs. The society has demanded an increased participation and accountability in public policies; at the same time, complex and specialized issues emerge in this environment and risky decisions need to be quickly made. The demand for good public policies has become more complicated, requiring more ability and skill from managers and policy-makers.

This study aims at addressing some relevant aspects of this dilemma, namely, social participation in public policies and the constant effort to engage society in the design and deployment of public policies. It focuses on the democratic features of a specific tool: public hearings. By pointing out the dynamics of the main actors and the nature of issues discussed in public hearings, this paper challenges the hypothesis of various scholars who have written about the social participation bias in this kind of procedure.

This way, this study investigates social participation in the public hearings about tariff review held by the Brazilian National Agency of Electric Energy (Aneel), particularly identifying the attendants and the nature of issues under discussion. The purpose is examining the actual role of this tool as a means for democratizing the decision making process.

We found out that most hearings held by Aneel are attended by experts, in spite of the politically-driven discussions. On the one hand, they are accessible to the lay public, but, on the other hand, they tend to deviate from the main debating point. In short, although these hearings do not reach a wider public, the attendants may guide the issues towards a less technical discussion. From this viewpoint, the following question emerges: "How can public hearings be used as a tool for political/individual promotion?". 
This paper is organized in six parts. The next section two has sought to provide a background of the electric power sector and some of the ways how society may participate in it. It introduces Aneel and the public hearings as a tool for citizen engagement with this regulatory agency. Section three explores the theoretical concepts and evaluation methods in participatory policies, as this approach is key to improve the research agenda for participation in public policies. Section four presents the methodological approaches used to examine the hearings, namely content and discourse analysis. Section five presents the results and, finally, the conclusion brings suggestions for further research.

\section{Contextualization}

During the 1980s and early 90s, the exploitation of electricity was performed mostly by public companies. However, back then, economic crises and the oil shock and its consequences brought difficulties in raising funds. In 1992, the trend of privatization in Brazil and the ideas of the Washington Consensus reached the electric power sector, and many companies were sold, settling a competitive wholesale market (Belyaev, 2011). At that time, Aneel was founded to deal with issues related to the increasing competition and private participation in the electric power sector. In a natural monopoly, such as the provision of electricity with high fixed costs, the company tends to minimize expenses, leading to very high prices or costs and to price structures which may prove to be ineffective. In this sense, regulation is "needed to constrain prices so that the firm earns neither excess nor insufficient profits; and regulate the structure of rates so that individual prices are efficient (at least in a second best sense)" (Joskow and Rose, 1987:8).

The regulatory agency, a special autarchy attached to the Brazilian Ministry of Mines and Energy (MME), constituted by means of the Law 9,427, enacted on December 26, 1996, should act as an impartial and independent authority. To guarantee its financial and managerial independence, the officials of Aneel enjoy a stable status, with a fixed term. Moreover, the agency should ensure safety in electricity supply, promote lower tariffs, and increase social participation.

In this context, many reasons may justify social participation in discussions on the Brazilian electric power sector (Jouravlev, 2007).

First, in order to protect the public interest, participation is a mechanism for ratifying/ discussing the issue with stakeholders, increasing regulatory transparency and compliance. According to Mattos (2005), democratic control mechanisms may be adopted to guarantee a legitimate regulatory action, through which the interests of the citizens concerned are expressed. These mechanisms have what Mattos names a "democratic potential", in spite of the decrease in the traditional political control mechanisms, usually put into action through the electoral process (vertical accountability).

Second, according to the modern economic theory, participation may be used to lessen information asymmetry between the regulator and the regulated companies, so that the poli- 
cies are based on more comprehensive data, combining the knowledge of officials and managers (Berg, 2000). Additionally, the struggle for strengthening participatory democracy is also apparent in the 1988 Brazilian Federal Constitution, in its articles $1^{\text {st }}$ and 58, § 2, II:

Article 1. The Federative Republic of Brazil, formed by the indissoluble union of the states and municipalities and of the federal district, is a legal democratic state and is founded on:

I - sovereignty;

II - citizenship;

III — the dignity of the human person;

IV — the social values of labour and of the free enterprise;

$\mathrm{V}$ - political pluralism.

(...)

Article 58. The national congress and both its houses shall have permanent and temporary committees, established in the manner and with the incumbencies set forth in the respective regulations or in the act from which their creation resulted.

(...)

Paragraph 2. The committees have the power, on account of the matter under their authority:

(...)

II — to hold public audiences with entities of civil society; (...).

To understand the increasing demand for participation, we also need to be aware of the growing social agenda in Brazil, especially after the increase in participatory budget and the Lula administration (2003-10). The system of participatory budget in Porto Alegre, Rio Grande do Sul, Brazil, is among the most successful cases of local management based on participatory democracy. At the same time, the Lula administration emphasized the social agenda, including citizens in the management of programs, by means of representation in local social councils.

Furthermore, the use of social participation in other regulatory agencies, as a best practice tool, has also influenced the public hearings initiative. According to the Regulation and Quality Improvement Authority (RQIA) (2008:4) of the United Kingdom Government, public participation plays an important role "through listening to and acting on the views and opinions of the public, RQIA will ensure that it responds to existing and emerging issues within health and social care (HSC)".

In this context, social participation, especially through public hearings, emerges at Aneel as a tool for inclusion, accountability, democratization, collection of information, and law compliance. Thus, the aim of analyzing public hearings is highlighting their strengths and constraints related to one of their goals, namely, democratization. Regarding democratization, Aneel also has other tools for social inclusion and consumer protection, such as the Consumer Council, public consultations, technical forum, and ombudsman. 
Public hearings at Aneel have been used to discuss contracts, internal regulations, and, mainly, tariff review, as provided by the Law 9,427/95, article $4^{\text {th }}$, $\S 3^{\circ}$, and the Decree 2,335 , enacted on October 6, 1997, article 21. These hearings may either be live or based on documentary exchange. Live hearings are open to the general public; the duly registered participants have the right to voice out their contributions and suggestions with regard to the issues under discussion. The participants should focus on issues included in the agenda. In some cases, and at the discretion of the Board of Directors, live public hearings may be simultaneously held at different locations, for promoting a broader participation of stakeholders.

In the particular case of tariff review, live hearings involve many steps: investment analysis, characterization of provision standards, discussion of public subsidies, and all other attributes which impact on costs. Indeed, this set of decisions has a political rather than a technical nature (Turolla, 2007).

According to Turolla (2007), establishing rates, in addition to technical definitions, involves public opinion and a high political cost. Unlike the definition of tariffs during the first negotiation, cases of tariff review include not only financial balance, but also a balance between investment planning and operational changes. Therefore, the new price may be supported by the regulator, but it is desirable that these kinds of balance result from political decisions. In these cases, it is up to the society to choose which aspect should be focused on the trade-off between rates and investments, since rates are directly related to the standard of services. Having this argument in mind and regarding tariff review as driven by cost and political concerns, Fischer (1993) and Perhac (1998) also claim that controversial and "wicked" topics seem to require further public participation.

\section{Rationale of social participation and its evaluation methods}

After the brief contextualization of the electric power sector and its participatory features, there is a need to have in mind some theoretical definitions and evaluation methods. As Chess and Purcell (1999:2685) observe, academic literature on public participation has grown rapidly. However, still there is no consensus, formula, or conclusion about its best results or improvements in policy making (Rosener, 1978).

Webler and Tuler (2002) indicate a number of conceptual approaches to understand public participation: management theory, collaborative learning, procedural justice, democracy theories, and decision making theories. Smith (1983 apud Rowe and Frewer, 2000), for instance, states that public participation comprises a set of procedures designed to hear, involve, and inform the public, allowing all those affected by a decision to have some access to that decision. Other authors, such as Day (1997), believe that public participation does not necessarily mean influence; resorting to Schatzow (1977), the author points out the intrinsic values of participation and advocates that procedural aspects also need to be taken into account. Participation, thus, refers to direct public involvement in decision making process, and 
this does not necessarily mean a public influence: "Instead, influence refers to the effect of public in decision making and operates even when the public does not actually participate" (Day, 1997:430).

This normative perspective of participation is based on the recognition of basic democratic rights, as well as on the understanding that it may promote intellectual and social development. Following Pateman (1970), the rationale of citizen participation is based on empowerment, inclusion, and education, regarding the society as made up of citizens instead of consumers (Stivers, 1990). These arguments advocating for citizen participation are based on the strengths of this process and on the belief that having an engaged citizenry is better than having a passive citizenry (Arnstein, 1969).

Given all the intellectual and social benefits of participation per se, as well as its potential as an information source, some political theorists claim that deliberative democracy should be adopted as a theoretical basis (Hoggett and Thompson, 2002), in order to achieve better results. The key idea is gathering all citizens under certain conditions, to engage them in discussions about issues of public interest. This process may facilitate the acceptance and legitimacy of decisions, since they emerged from a deliberative process.

The definition of deliberative democracy significantly differ from author to author; nevertheless, the key idea involves collective decision making with participation of stakeholders (democracy), by means of arguments exchanged between participants, who are committed to the values of rationality and impartiality (deliberation).

Overall, the main aim of deliberative democracy is providing the most effective way for dealing with disagreements in politics. Thus, deliberative democracy has four related purposes: promote the legitimacy of collective decisions; encourage public-driven perspectives on public issues; promote mutually respectful processes for decision making; and help correcting possible mistakes made by citizens and officials when they take collective actions (Gutmann and Thompson, 2004).

Habermas (1987), with his theory of communicative action, also sheds some light on the plausibility and need for deliberative democracy in the public administration. He argues that, although instrumentality is the crucial norm for social action at the administrative level, there are rationality ways in the "lifeworld" which do not follow the same logic, and the author names them "communicative rationality". "Lifeworld" is defined as a "sphere of interaction centered on culture, society, and personality, where communication plays a big role not only for expression but also for justification and argumentation" (Kelly, 2004:43).

Nevertheless, free communication, uncritical and blind inclusion of citizens in public policies, is not enough to promote empowerment, engagement, and effective deliberative democracy; the tools available to do that need to be better evaluated and understood. Success in this regard can only be achieved through a better use of tools properly adjusted to achieve the desired goal.

The most liberal view may lead to an overenthusiastic embrace of participatory procedures, believing that citizen participation alone can improve policies. That is not the case. 
The effectiveness of participation is related to realize the problem and address its complexity with a critical view. We do not claim that just increasing opportunities for the participation of citizens in public policies have a positive effect; rather, we focus on how and when the policymaker can apply tools for providing citizens with opportunities to effectively participate in public policies.

Looking for continued participation of citizens, public hearings emerge as an important tool for direct participation. As Checkoway (1981:566) notices: "Public hearings are among the most traditional methods for citizen participation in America. They are required at all levels of government and are increasing in number and use". In spite of the frequently negative reviews on the public hearings and the development of a large body of literature about alternative techniques for citizen engagement, it is still the technique of choice with regard to various issues (Kihl, 1985).

To emphasize the effectiveness of this tool, Kihl (1985:199) claims that it "responds to public demands rather than generating frustration". The author highlights that, perhaps, this kind of participation promotes and enhances individual leadership qualities, personal growth, and awareness of government, as well as the public policy planning. In short, this process may lead to a better and more informed citizenry.

Analyzing procedures in hearings, Rowe and Frewer (2000) and Irvin and Stansbury (2004) observe that they are limited to engaged citizens; the actual participants are experts. "It has been used to respond the demand of public participation, getting a group of citizens together so that they can be persuaded by the official point of view" (Rowe and Frewer, 2000:10). Such participation methods (referenda and public hearings) seem to be employed just for meeting public involvement needs, regarding them as an end in themselves rather than a tool with a specific purpose.

Fiorino (1990) presents four criteria to assess public involvement and public hearing: (i) the direct participation of amateurs in decision making; (ii) the participation of citizens in collective decision making; (iii) the length of time available for a face to face discussion; and (iv) the opportunity for citizens to participate on an equal basis with administrative officials and technical experts.

Checkoway (1981) indicates many studies following this argumentation. Accordingly, people with low income and those under 18 years of age tend to be inadequately represented and unable to make significant contributions. The authors discuss an extensive literature claiming that those who attend public hearings are not representatives of the population; they are often dominated by people able to invest and make significant contributions.

Regarding the participatory policy issues discussed, Dietz et al. (1989), examining public hearings on environmental issues, identify an attempt by the agency to focus on technical discussions - its staff is more fluent in this language. Thus, the officials may be able and confident to guide the debate in a better way.

Similar findings are also presented by Topal (2009); according to this author, public hearings have been used to "legitimate practices and enact institutional power" (Topal, 
2009:277), in order to meet particular rather than general needs. This way, they legitimate actions taken by the government and companies by showing citizen participation, general interest, and rational evaluation. Considering that the board and the company are represented by experts while other parties are not, the technical arguments are not put into question; the companies tend to have an advantage in terms of technical participation. Hence, the participation of citizens in public hearings has a formal rather than practical nature.

Given the above, the following section analyzes the hypothesis of biased participation of citizens in the public hearings held by Aneel during the second cycle of a tariff review.

\section{Methodology}

This case study is based on several analytical units (hearings) which took place during the second cycle of a tariff review, held throughout Brazil from 2007 to 2009. The empirical investigation adopted content and discourse analysis as its theoretical framework, in order to evaluate the reports of hearings. In addition, interviews and informal conversations were conducted with various actors who are familiar with this context, such as directors of Aneel, officials at State regulatory agencies, members of the Consumer Council, and other stakeholders.

Following the steps adopted by Gephart (1993:1479), data was selected by means of "theoretical sampling, a process by which a researcher decides on analytic grounds which data to collect and analyze in the secondary stage of a project". The sampling criteria is described below.

\subsection{Sampling}

This research focuses on live public hearings held during the second cycle of a tariff review. Since the beginning of the public hearings, live discussions about tariff review are the key issue at Aneel; 27\% out of the 123 public hearings held by Aneel from 1998 to 2010 addressed tariff review in the electric power sector.

Focusing on the second cycle of a tariff review, 49 public hearings were identified, without taking into account the previous methodological discussions and technical hearings. However, a narrower sample of 26 hearings was selected, according to the following criteria: the public hearings have to represent every Brazilian region, as well as every Brazilian state (Table 1). Among these 26 hearings, 2, about methodology, led to the following question: "Do the attendance and the topics discussed in these hearings differ from those discussing tariffs on a regional basis?".

All data analyzed was obtained from the website of Annel. 


\begin{tabular}{|lccc|}
\multicolumn{5}{c}{ Table 1 } \\
\multicolumn{1}{c}{ Representation of regions } \\
\hline REGIONS & $2008-10$ & SAMPLE & $\%$ \\
\hline North & 4 & 2 & $50 \%$ \\
Northeast & 10 & 5 & $50 \%$ \\
Central-West & 6 & 3 & $50 \%$ \\
Southeast & 12 & 6 & $50 \%$ \\
South & 17 & 8 & $47 \%$ \\
Total & 49 & 24 & $49 \%$ \\
\hline
\end{tabular}

Source: Prepared by the author.

\subsection{Actors}

Having the sample on hand, the next step was analyzing the groups involved in the public hearings. The rules and organizational procedures for the public hearings at Aneel indicate the degree of participation allowed. The rules of Aneel do not differ from most kinds of hearing (Fiorino, 1990; Rowe and Frewer, 2000) with regard to the openness of this procedure. In the research field, with emergent coding, the categories were established according to a preliminary examination of data (Stemler, 2001). These categories are: consumers or their representatives, regulated companies, regulatory agencies, private companies and associations interested in electric power, trade unions, governmental organizations (Executive, Legislative, and Judicial powers, as well as political parties), non-governmental organizations, environmental groups, advisory companies, lawyers, students, and others.

"Private companies and associations interested in electric power" are defined as any organization with commercial aims who attended the hearing. "Governmental organizations" include ministries, state governments, and municipal administrations, state and municipal departments, public defenders, congressmen, city councilmen and their advisors, and other State agencies. "Non-governmental organizations" consist of all associations but the Consumer Council which have some interest in the public hearing; the only exception was the "Environmental groups", key stakeholders. Thus, whenever a governmental or non-governmental agency focused on environmental issues attended the public hearing, they were classified into a different group.

\subsection{Topics under discussion}

By pointing out the main issues discussed in public hearings for tariff review, we aim to analyze the language used during these meetings and its accessibility to the attendants. The methodology adopted was content analysis, according to its thematic approach. 
As Weber (1990:9) highlights, content analysis can be used to "reveal the focus of individual, group, institutional, or social attention". It assumes that groups of words reveal underlying themes and approaches. Using a set of procedures to categorize communications, content analysis provides researchers with opportunities to study values, intentions, and ideologies in discourses (Rogers et. al., 2005). Content analysis has several advantages, for instance: (i) when compared to techniques such as the interview, participants are not aware of the analysis and, hence, there is hardly any danger that the research will motivate a behavioral change; (ii) focus on communication, operating directly on transcripts of human communication; (iii) data is available for a long period of time, thus, it may always be reused. By looking at the text, the question tackles recurrent themes, which may be identified through what has been said. The key idea is classifying the words of a text into content categories. followed:

In this research, the steps proposed by Weber (1990) for content analysis were strictly

1) Define the recording units, in which any reference (positive, negative, or neutral) to tariff or electric power companies is made. In this case: sentences;

2) Select a sample and classify the main content of each sentence into certain established categories;

3) Assess the reliability of these categories, by means of replicability and stability. Thus, other researchers, graduated in Public Administration and familiar with the issue, were asked to code the same sample, in order to cross-check the consistency;

4) Disagreements and differences with regard to the categories were discussed among coders, giving rise to new coding rules;

5) The reliability was assessed, and a random sample of reports was provided to each coder, again.

The adoption of human coders, instead of computer softwares designed for this purpose, is mainly due to validity concerns. Human coders provide the research with "the opportunity to freely specify the meanings in the text we seek to categorize" (Shapiro, 2009:234), and they do not restrict the theoretical framework. Although human coders may be less effective in terms of time, costs, and ability, they are more effective to recognize ambiguities in the text and classify them into categories, providing the results with an increased validity.

The main ideas and arguments used by speakers during the hearings were grouped according to their content; 12 categories were identified: (i) cost-shifting/tariff burdens; (ii) tariff analysis and variables of reference firms; (iii) financial balance, investment, and effectiveness; (iv) taxes and governmental issues; (v) workers issues; (vi) self-promotion/private issues/political marketing; (vii) specific regional arguments; (viii) issues about tariff price; (ix) energy/service quality; (x) social responsibility, programs/subsidies/partnerships; (xi) procedures for public hearings; (xii) others. 
This classification into 12 categories proved to be useful for addressing the various demands discussed in public hearings. Some categories are rather politically-driven and others are more economically/technically-driven. In the first group, we may include issues related to personal values, such as: workers issues and concerns, self-promotion/private issues/political marketing, (high or low) tariff price and energy/service quality, as well as debates on the importance of social responsibility programs/partnerships/subsidies. Here, we can see that common features addressed to these categories, as "high" or "low", "fair" or "unfair", "good" or "not good", "many" or "much" are not absolute; they depend on personal experiences and viewpoints regarding fairness. Moreover, the classification covers private issues and self-promotion, which were not directly related to the topic under discussion and, also, contributions related to social programs conducted by the agency.

The arguments more economically/technically driven are those involving cost-shifting/ tariff burdens, analysis of components of tariff and comparison with a reference firm, financial balance, investments, and effectiveness; they are mostly based on trade-offs related to economic terms and values. These categories deal with items pre-established in the contracts, contract compliance, economic balance of contracts, issues related to investments, target accomplishment, costs, market effectiveness, and so on. It underscores an attempt to achieve neutrality and impartial arguments, being mostly based on complex and technical issues, where experts are better informed. The main arguments cover variables of tariff equation: $\mathrm{X}$ factor, factors A and B; specific legal discussions or other definitions with regard to the criteria for tariff settlement.

\section{Findings}

\subsection{Who are the participants?}

The group of regulated agencies is almost two times bigger than that of consumers: $31 \%$ versus $15.2 \%$. Thus, attendance seems to be dominated by the most interested group, i.e. the regulated companies.

It seems that there is a need to create tools to motivate the participation of lay people. In other words, policy-makers must make relevant information easily available in order to increase the attendance of citizens. Especially considering that, nowadays, most Brazilian citizens do not have access to the internet, other communication media, such as television and grassroots campaigns may also be used to increase social awareness.

Besides, motivation may also take the form of economic interest; the lack of social participation may be due to difficulties related to costs of transportation, lodging, and so on. Moreover, difficulties in grasping the subject of discussion and the time spent to understand the issues concerned seem to influence the low levels of consumer attendance. Therefore, at least during regulatory public hearings, some assistance may be provided, such as legal advice, access to documents, and reimbursement of participation expenses. 
Two public hearings discussing methodological definitions show a different context, even more dominated by the regulated companies; $56.3 \%$ of their attendants were regulated companies, followed by advisory and law firms, with $13.5 \%$ each. Private firms, governmental organizations, and regulatory agencies also attend the public hearings, with 8.1\%, 7.57\%, and 3.1\%, respectively. Surprisingly, consumers are almost not represented (Graph 1). In one of these public hearings, there were only 3 members of the Consumer Council among a total of 125 people; in the other methodological public hearing, there was no representative of consumers at all.

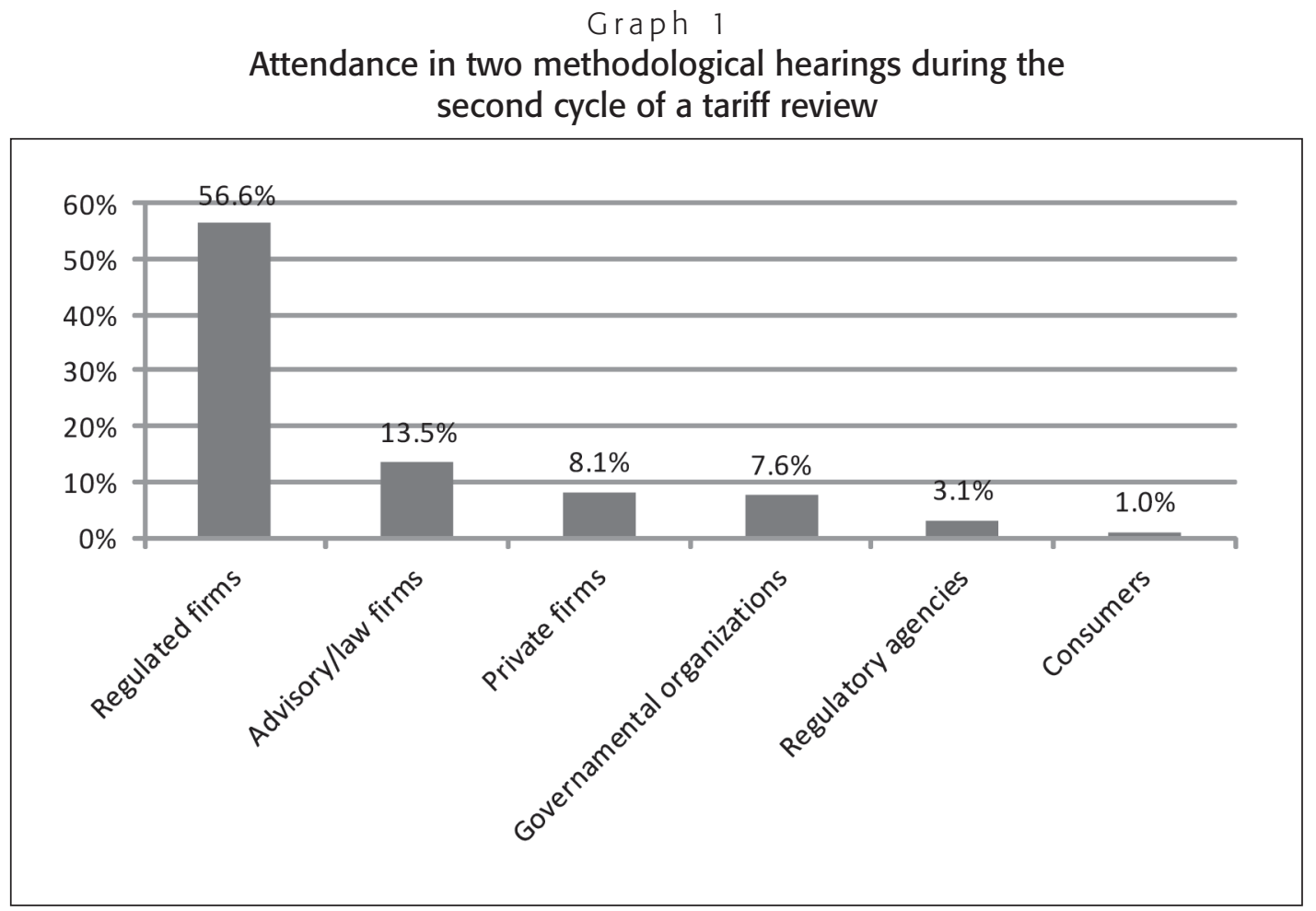

Source: Prepared by the author.

Regarding technical discussions, some authors (Day, 1997) advocate for a pluralist rather than a direct participation; however, this was not observed in the methodological public hearings. The results show that neither the citizens themselves nor the representatives attend the public hearings. If the emphasis here lies on outcomes instead of educational benefits, the groups of stakeholders still need to have the opportunity to access officials; if they do not attend the public hearings, it seems very difficult to achieve an actual pluralistic system.

The use of alternative tools for participation may help this process. Consumers should be equipped to fully understand and supervise the discussion of the issues concerned. These 
actions, as a whole, may contribute to what Pateman (1970) names "political equality", motivating the lay public and providing it with means to attend and influence the process.

In the methodological public hearings, the predominance of technical topics also underscores the need for other participation procedures. Civil society must be aware of the discussions and able to attend and grasp the subject of discussions. Indeed, public hearings alone cannot promote social participation.

In this regard, it is worth highlighting the panels, which may be used to deal with more complex issues. This kind of procedure focus on qualification and each participant has the opportunity to take part in a deeper discussion about rather technical topics. The panel, in contrast to the typical limited five-minute format used in public hearings, enables more interactive citizen participation (Kathlene and Martin, 1991) and it allows dealing with a wide range of tasks and settings; the learning process is key to participation. Simple description of trade-offs with regard to effectiveness and democratic level may no longer be used as an excuse to restrict public participation or accept the absence of it. Policy issues with particularly difficult practical problems may respond in a better way to a rather knowledgedriven participation. We think these mechanisms can make more progress in order to deal with complex issues.

Other tools, more effective to provide the lay public with information and ask for its opinion, may also be adapted according to the issue concerned, for instance, interview, peer review, etc. These seem to be better ways to embody public value and generate alternatives and outcomes (Beierle, 2010). They may be put into action at home or through surveys by mail; the first promote a two-way communication between the participant and the interviewer and make more information available to participants, the second can address a larger public, fit into personal time schedules, and provide the time needed for an in-depth analysis (Kathlene and Martin, 1991). Besides, peer review can provide opportunities for information exchange among senior managers and other experts, for instance, by means of regular meetings and other channels of knowledge management.

\subsection{Key topics: are they technically-driven?}

This section, based on speeches in reports, addresses the nature of topics under discussion in the public hearings. According to the rules of Aneel, every public hearing starts with the presentation by an expert, who explains technical mechanisms and subsidies used in a tariff review. As these presentations follow the same pattern in all public hearings and, to some extent, do not restrict the intervention by attendants, they were not taken into account, as well as the short interruptions or explanations by Aneel in the end of each public hearing, since they were always related to questions or doubts presented by some attendant.

Overall, the results show that the most frequently discussed topics are rather politicallydriven, such as the definition of service quality (14.3\%), self-promotion, and private issues (13.2\%). Social responsibility and partnership (9.4\%) also represent a large percentage, as 
well as differences in price (10.6\%). The rather technically-driven topics (such as cost-shifting/tariff burdens, analysis of components of tariff, and comparison with a reference firm) also have a significant overall representativeness (around $21 \%$ of topics under discussion) (Graph 2).

\section{Graph 2}

The most frequently discussed topics in the public hearings from 2007 to 2010

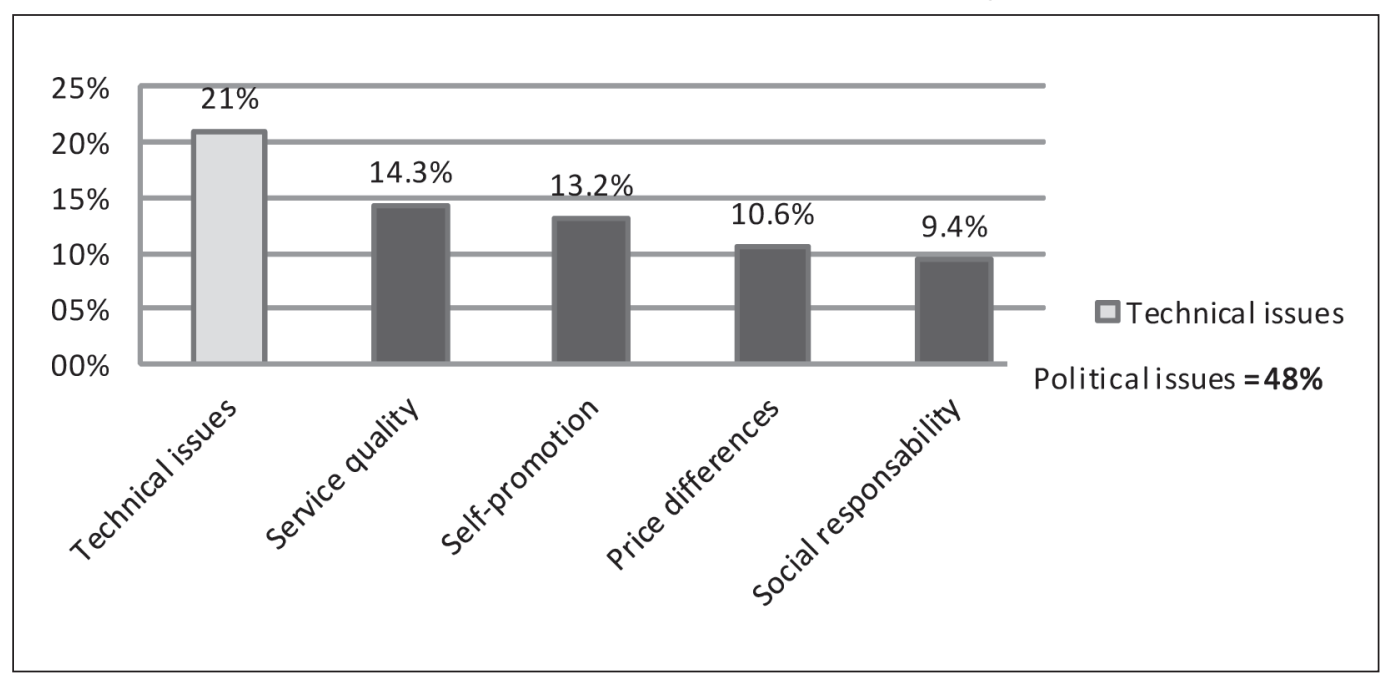

Source: Prepared by the author.

Technical issues do not play a significant role in the public hearings. Although most attendants are related to the regulated companies, the public hearings seem to be an effective tool for providing the lay public with an opportunity for an active contribution.

Nevertheless, the same pattern is not observed if we consider the two methodological hearings mentioned above; they had a predominance of technical discussions addressing analytical methodologies and variables (44.6\%), as well as economic aspects with regard to investments and financial balance (24.6\%). Discussions about price and service quality also play a rather insignificant role and issues about government and social responsibility are not even mentioned.

We can notice that the participation pattern has considerably changed over the years. A number of non-governmental organizations and politicians have also used the public hearings for political marketing, instigating conflict and misleading discussions, instead of providing technical discussions with support. Besides, although these actors seem to be important stakeholders in order to balance the topics under discussion, their participation can bring negative impacts on the public hearings; instead of being used as a tool to increase awareness, compliance, and citizenry, the public hearings could be used to increase conflict and promote an electioneering arena. Thus, the public hearing should have clear rules and the organizer 
may promote an educational campaign about the actual proposal of a public hearing. It will not, however, completely eliminate the electioneering impulses, which are natural in a democratic environment, but a public hearing may avoid excesses and provide better outcomes. In order to draw strong conclusions on this subject, further research may focus on the promotional use of public hearings by government and politicians, analyzing its risks and benefits.

The next step consists of searching a way how to lead the discussions and conclusions from public hearings to further developments. A more effective participation is obtained when people are able to make recommendations to the policy-makers. The attendants must be empowered, i.e. they must be able to provide a direct contribution to the decision making process, influencing on outcomes and impacts related to public policies. This increases not only the possibility of creating but also implementing effective public policies, with greater social acceptance. If citizens realize that their viewpoints have not been taken into account, they may put these policies into question.

Some interviews pointed out that the time frame of a public hearing is also relevant in order to motivate attendance and increase effectiveness. In short, there is a need to include the public opinion into the discussion of public policies, instead of restricting it to the approval phases. Thus, this issue is also worth addressing in further researches. Participation must be regarded as decisive and influential, and not only as a justification for a previous decision.

\subsection{Actors $\times$ topics under discussion}

Regarding the topics under discussion and the actors involved with this, we can notice how weak is the role played by the consumer representatives. Instead of acting as the technical arm of consumers, they have focused on self-promotion and provided a fragile approach to technical issues; as a result, consumers and private companies have also used this tool for selfpromotion and to debate private issues, deviating from the primary focus of debate. On the other hand, regulated companies, representatives of private companies, and advisory firms bring rather technical concerns, addressing financial balance, effectiveness, and investment. In turn, governmental and non-governmental organizations emphasize quality issues, more closely related to political and personal values.

It seems that the consumer representatives have a limited ability to empower social voices and address complex issues. Thus, the need to strengthen these organizations becomes evident. More than follow decisions, these organizations should be empowered by means of a decentralized and participatory management. Given the asymmetry between technical and financial resources of consumer entities, we emphasize the need for providing them with resources able to enable an actual consumer protection. These asymmetries hinder consumer participation in regulatory processes, and, therefore, end up constituting a barrier to consumer viewpoints.

Here, we can identify two main alternatives to increase the power of consumer protection agencies: by means of the supportive role of regulatory agencies or through financial 
support guaranteed by law. The first option, which has been adopted in Brazil, is still incipient and it deals with the creation and expansion of the Consumer Council. The current version of the Bill 3,337/2004 reinforces the interaction between regulatory agencies and consumer protection organizations. Its article 31 provides that regulatory agencies should foster the inclusion of consumer protection organizations into regulatory processes, guaranteeing their effective participation. The Bill 3,337/2004 defines the regulatory agency according to its public and institutional role, with particular rights and duties. Thus, the power granted by the 1988 Brazilian Federal Constitution to these agencies needs to be justified through a more active engagement of civil society. However, this option may lead to great risks, since regulatory agencies can influence and guide the steps taken by the Consumer Council.

The second option also deals with the support to consumers by their representatives. Nevertheless, it relies on independent budget of the Consumer Council. The financial resources should be, therefore, guaranteed by law and they may also come from consumers themselves or fines or penalties applied by regulatory agencies. This option may guarantee long and stable life to councils, but they need much more political power and willingness; the idea is not decreasing any support for the agencies, something which is a constitutional right, but decreasing their influence on consumers. The council should be a space for continued debate, increased engagement, and active participation.

\section{Conclusion}

This study presented a democratic dilemma with regard to the participation of lay citizens in the discussion of public policies. If the public hearings held by Aneel aim to get closer to the civil society what has this tool actually achieved? Which sphere of civil society has actually participated in it? To what extent can the lay public participate and contribute to these debates? These are some questions addressed in this paper.

In order to provide them with answers, at first, there is a need to have in mind the nature of public hearings under analysis; all discussions and results must be explored from the perspective of tariff review and the attention that this kind of hearing can attract. However, based on Fischer (1993) and Perhac (1989), more controversial and "wicked" topics, such as tariff review, seem to require an increased public participation, since they are more economically/politically-driven and seem to attract much attention from the lay public, thus drawing conclusions which cannot be generalized as a whole. These characteristics are crucial to this paper.

The literature show that the public hearings held by Aneel are mostly attended by the regulated companies and, at the same time, the consumer representatives have a limited ability to empower social voices and address complex issues. Therefore, in order to make this group stronger, there is a need to provide consumers with other ways to participate and the consumer organizations, such as the Consumer Council, should become more empowered. 
On the other hand, the predominance of political topics during the discussions in the public hearing contradicts the literature. Without discussing the immediate impact on policies and the contents relevance, we need to acknowledge that these topics provide the consumers and lay public with an increased possibility to participate in public hearings. Nevertheless, a significant concern is related to the misuse of public hearings; instead of providing a space able to increase awareness by means of discussions, the public hearings can be used to increase conflict and promote an electioneering arena.

The public hearings play a significant role as a tool to increase public participation and inclusion into public policies. Using Aneel as a case study showed the abilities of this agency as a democratic institution and, at the same time, we also observed its limitations, especially when dealing with complex issues. Public hearings cannot be regarded as a final solution; there is a need to adopt other methodologies and mechanisms, able to deal with constraints related to social motivation to turn formal participation into practical participation.

Therefore, both the citizens and the policy-makers need to learn more about the way how conducting public hearings, so that they become more democratic and legitimate tools to support the creation of effective public policies.

\section{References}

ARNSTEIN, Sherry R. A Ladder of Citizen Participation. Journal of the American Institute of Planners, v. 35, n. 3, p. 216-224, 1969.

ASHLEY, Richard K. Three Modes of Economism. International Studies Quarterly, v. 27, n. 4, p. 463-496, 1983.

BEIERLE, Thomas C. Using Social Goals to Evaluate Public Participation in Environmental Decisions. Policy Studies Review, v. 16, n. 3, p. 269-286, July/Sept. 2010.

BELYAEV, Lev S. Electricity Market Reforms Economics and Policy Challenges. Springer New York, p. 51-75; p. 177-201, 2011.

BERG, Sanford. Developments in Best Practice Regulation: Process vs. Performance. In: PREPARED FOR INCENTIVE REGULATION AND OVERSEAS DEVELOPMENT CONFERENCE, 2000, Sydney. Disponível em: <http://warrington.ufl.edu/centers/purc/purcdocs/papers/9902_Berg_Developments_in_Best.pdf $>$. Acesso em: 10 jun. 2013

BRASIL. Constitution of Federative Republic of Brazil. Disponível em: < http://bd.camara.gov.br/ bd/bitstream/handle/bdcamara/1344/constituicao_ingles_3ed.pdf?sequence $=7>$. Acesso em: 10 ago. 2013.

CHECKOWAY, Barry. The politics of public hearings. Journal of Applied Behavioral Science, v. 17, n. 4, p. 566-582, 1981.

CHESS, Caron; PURCELL, Kristen. Public Participation and the Environment: Do We Know What Works? Environmental Science \& Technology, v. 33, n. 16, p. 2685-2692, Aug. 1999. 
DAY, Diane. Citizen participation in the planning process: An essentially contested concept? Journal of Planning Literature, v. 11, n. 3, p. 412-434, 1997.

DIETZ, Thomas; STERN, Paul C.; RYCROFT, Robert W. Definitions of conflict and the legitimation of resources: the case of environmental risk. Sociological Forum, v. 4, n. 1, p. 47-69, 1989.

FIORINO, Daniel J. Citizen Participation and Environmental Risk: A Survey of Institutional Mechanisms. Science, Technology \& Human Values, v. 15, n. 2, p. 226-43, 1990.

FISCHER, Frank. Citizen Participation and the Democratization of Policy Expertise: From Theoretical Inquiry to Practical Cases. Policy Sciences, v. 26, n. 3, p. 165-187, 1993.

GEPHART, Robert P. The Textual Approach: Risk and Blame in Disaster Sensemaking. The Academy of Management Journal, v. 36, n. 6, p. 1465-1514, 1993.

GUTMANN, Amy; Thompson, Dennis. Why Deliberative Democracy? Princeton: Princeton University Press, 2004. Chap. 1.

HABERMAS, Jürgen. The theory of communicative action. Boston: Beacon Press, 1987.

HOGGETT, Paul; THOMPSON, Simon. Toward a Democracy of the Emotions. Constellations, v. 9, n. 1, p. 106-126, 2002.

IRVIN, Renée A.; STANSBURY, John. Citizen Participation in Decision Making: Is It Worth the Effort? Public Administration Review, v. 64, n. 1, p. 55-65, 2004.

JOSKOW, Paul L.; ROSE, Nancy L. The effects of economic regulation. Cambridge: MIT, n. 447, 1987.

JOURAVLEV, Andrei. Participação dos consumidores no processo regulatório. In: GALVÃO JUNIOR, Alceu de C.; XIMENES, Marfisa M. Regulação: controle social da prestação dos serviços de água e esgoto. Fortaleza: Pouchain Ramos, 2007. p. 19-36.

KATHLENE, Lyn; MARTIN, John A. Enhancing Citizen Participation: Panel Designs, Perspectives, and Policy Formation. Journal of Policy Analysis and Management, v. 10, n. 1, p. 46-63, 1991.

KELLY, Terrence. Unlocking the iron cage: Public Administration in the Deliberative Democratic Theory of Jürgen Habermas. Administration \& Society, v. 36, n. 1, p. 38-61, 2004.

KIHL, Mary R. The Viability of Public Hearings in Transportation Planning. Journal of Applied Behavioral Science, v. 21, n. 2, p. 185-200, 1985.

MATTOS, Paulo T. L. Regulação econômica e social e participação pública no Brasil. Regulação Brasil, n. 1, p. 109-147, 2005.

PATEMAN, Carole. Participation and Democratic Theory. London: Cambridge University Press, 1970.

PERHAC JR., Ralph M. Comparative Risk Assessment: Where Does the Public Fit In? Science, Technology, \& Human Values, v. 23, n. 2, p. 221-241, 1998. 
REGULATION AND QUALITY IMPROVEMENT AUTHORITY (RQIA). Public Participation Strategy. Uk Government, v. 1, n. 1, p. 1-18, 2008. Disponível em: <www.rqia.org.uk/what_we_do/public_participation.cfm >. Acesso em: 10 jun. 2013.

ROGERS, Rebecca et. al. Critical Discourse Analysis in Education: A Review of the Literature. Review of Educational Research, v. 75, n. 3, p. 365-416, 2005.

ROSENER, Judy B. Citizen participation: Can we measure its effectiveness? Public Administration Review, v. 38, n. 5, p. 457-463, Sept./Oct. 1978.

ROWE, Gene; FREWER, Lynn J. Public participation methods: A framework for evaluation. Science, Technology, \& Human Values, v. 25, n. 1, p. 3-29, 2000.

SCHATZOW, Steven. The influence of the public in environmental decision making in Canada. In: SEWELL, Derrick; COPPOCK, John. T. (ed.). Public Participation in Planning. London: Wiley, 1977. p. 41-158.

SHAPIRO, Gilbert. The future of coders: Human judgments in a world of sophisticated software. In: KRIPPENDORFF, Klaus; BOCK, Mary A. (Ed.). The content analysis reader. California: Sage Publications, 2009. p. 234-242.

SMITH, L. Graham. Impact assessment and sustainable resource management. Harlow, UK: Longman, 1983.

STEMLER, Steve. An Overview of Content Analysis. Practical Assessment, Research \& Evaluation, v. 7, n. 17, p. n/a, 2001.

STIVERS, Camilla. The Public Agency as Polis: Active Citizenship in the Administrative State. Administration \& Society, v. 22, n. 1, p. 86-105, 1990.

TOPAL, Cagri. The Construction of General Public Interest: Risk, Legitimacy, and Power in a Public Hearing. Organization Studies, v. 30, n. 2-3, p. 277-300, 2009.

TUROLLA, Frederico. Participação social na definição de tarifas. In: GALVÃO JUNIOR, Alceu de C.; XIMENES, Marfisa M. F. Regulação: controle social da prestação dos serviços de água e esgoto. Fortaleza: Abar; Pouchain Ramos, 2007. p. 95-113.

WEBER, Robert P. Basic Content Analysis. Newbury Park, CA: Sage, 1990.

WEBLER, Thomas; TULER, Seth. Unlocking the Puzzle of Public Participation Bulletin of Science. Technology \& Society, v. 22, n. 3, p. 179-189, 2002.

Camila Moreira de Castro is Master in Public Management from the Zeppelin University. Advisor at the Civil House of the Brazilian Republic Presidency. E-mail: castrocamila50@gmail.com. 
